\title{
Orofacial Disorders of Patients with End Stage Renal Disease Undergoing Haemodialysis
}

\author{
Yohana Gowara ${ }^{1}$, Afi S. Sarsito ${ }^{2}$, Parlindungan Siregar ${ }^{3}$, Yuniardini S. Wimardhani ${ }^{2}$ \\ ${ }^{1}$ Oral Medicine Residency Program, Faculty of Dentistry, Universitas Indonesia, Jakarta 10430, Indonesia \\ ${ }^{2}$ Department of Oral Medicine, Faculty of Dentistry, Universitas Indonesia, Jakarta 10430, Indonesia \\ ${ }^{3}$ Department of Internal Medicine, Faculty of Medicine, Universitas Indonesia, Jakarta 10430, Indonesia \\ Corresponding e-mail to: ygowara@yahoo.com
}

\begin{abstract}
ABSRACT
Several orofacial disorders in patients with end stage renal disease (ESRD) undergoing hemodialysis have been reported. However, up to the present, particularly in Indonesia, such data still limited. Objective: the purpose of this study was to assess the orofacial disorders in patients with ESDR undergoing hemodialysis at Cipto Mangunkusumo Hospital, Indonesia. Methods: The study was conducted through observation using a cross-sectional design. The subjects were selected by consecutive sampling. Ninety-three patients fulfilled the inclusion criteria and enrolled in this study. They participated in the structural interview-using questionnaire assessing subjective complaints; clinical examinations; and salivary measurements. Results: Xerostomia (82.8\%) dysgeusia (66.7\%), metal taste (57\%), perioral anesthesia $(24.7 \%)$ were the common symptoms. Clinical findings consisted of tongue coating (100\%), calculus deposits (97.8\%), pallor of oral mucous (94.6\%), sialosis (75.3\%), uremic odor (40,9\%), haemorrhagic spot (39.8\%), angular cheilitis (37.7\%), gingival bleeding (15.1\%), and oral candidiasis $(3.2 \%)$ were also found. Salivary changes showed the increase of salivary viscosity $(86 \%), \mathrm{pH}(80.6 \%)$, buffer capacity $(76.3 \%)$ whereas decrease of mucous hydration level (79.6\%) and the flow rates of unstimulated (22.6\%) and stimulated (31.2\%) whole saliva were observed. Conclusion: The findings of orofacial disorders required attention and further comprehensive management to enhance the quality of life of patients with ESDR.
\end{abstract}

\begin{abstract}
ABSTRAK
Kelainan regio orofasial pada GGT pasien gagal ginjal terminal (GGT) yang menjalani hemodialisis. Beberapa kelaian orofasial pada pasien gagal ginjal terminal yang menjalani hemodialisis telah dilaporkan. Namun, sampai saat ini, terutama di Indonesia, data yang ada tentang hal tersebut masih sangat terbatas. Tujuan: Penelitian ini bertujuan untuk mengetahui kelainan orofasial pada pasien GGT yang menjalani hemodialisis di Rumah Sakit Cipto Mangunkusumo, Indonesia. Metode: Desain penelitian adalah studi observasi potong lintang. Subjek penelitian dipilih berdasarkan metode consecutive sampling. Sebanyak 93 pasien yang memenuhi kriteria inklusi merupakan subjek penelitian ini. Subjek berpartisipasi dalam wawancara menggunakan kuesioner yang menanyakan tentang adanya keluhan subjektif, pemeriksaan klinis dan pengukuran saliva. Hasil: Serostomia (82,8\%), dysgeusia (66,7\%), rasa metal (57\%), rasa baal perioral (24,7\%) merupakan gejala yang sering ditemukan. Temuan klinis meliputi tongue coating (100\%), deposit kalkulus $(97,8 \%)$, mukosa mulut yang pucat $(94,6 \%)$, sialosis $(75,3 \%)$, bau uremik $(40,9 \%)$, bercak hemoragik (39,8\%), angular keilitis (37,7\%), perdarahan gingival (15,1\%), dan kandidiasis oral (3,2\%). Perubahan saliva terkait peningkatan viskositas $(86 \%), \mathrm{pH}(80,6 \%)$, kapasitas dapar (76,3\%). Selanjutnya terjadi pengurangan tingkat hidrasi mukosa $(79,6 \%)$ dan laju alir saliva tanpa stimulasi $(22,6 \%)$ dan dengan stimulasi (31,2\%). Simpulan: Temuan kelaianan orofasial pada penelitian ini membutuhkan perhatian dan penanganan yang menyeluruh untuk meningkatkan kualitas hidup pasien dengan gagal gingjal terminal GGT.
\end{abstract}

Key words: end stage renal disease, oral mucosa, orofacial disorder, saliva 


\section{PENDAHULUAN}

Gagal ginjal kronik (GGK) merupakan suatu sindrom klinis yang disebabkan oleh kerusakan fungsi ginjal yan bersifat menahun dan progresif. ${ }^{1}$ Penyakit ini memiliki etiologi yang beragam dan kompleks. Saat ini lebih dari $50 \%$ kasus gagal ginjal kronis berkaitan dengan diabetes melitus dan hipertensi. ${ }^{2}$ Kecenderungan peningkatan prevalensi diabetes dan hipertensi, secara tidak langsung dapat meningkatkan komplikasi penyakit, antara lain resiko terjadinya GGK. ${ }^{2,3}$

Di negara-negara maju didapatkan variasi prevalensi dan insidensi gagal ginjal tahap terminal (GGT) yang cukup besar. Insidensi berkisar antara 77-283 per juta penduduk, sedangkan prevalensi yang menjalani hemodialisis antara 476-1150 per juta penduduk. ${ }^{1}$ Berdasarkan data National Kidney Foundation K/ DOQI tahun 1996, sekitar 284.000 penduduk Amerika menderita GGT atau lebih dikenal dengan End Stage Renal Disease (ESRD). ${ }^{3}$ Sebesar $62 \%$ dari angka tersebut membutuhkan perawatan hemodialisis. Menurut data National Registry tahun 1999, sebanyak 17.948 orang menderita GGT dan 68\% di antaranya perlu menjalani hemodialisis. ${ }^{3}$

Data prevalensi pasien GGK di Indonesia dapat dikatakan belum ada, karena studi epidemiologi mengenai penyakit ini masih sangat terbatas. Hal ini disebabkan di Indonesia sampai saat ini belum terdapat penelitian yang bersifat nasional dan multisenter, yang dapat menggambarkan prevalensi GGT dengan tepat. Selain itu seringkali pasien GGK tidak terdiagnosis atau tidak dirujuk ke rumah sakit. Dengan demikian data yang ada adalah banyaknya pasien GGK yang masuk fase terminal (GGT) karena membutuhkan atau sedang menjalani terapi hemodialisis. Berdasarkan data tersebut, diperkirakan pasien GGK adalah sekitar 2000 per juta penduduk Indonesia. Informasi dari bagian hemodialisis Rumah Sakit Umum Pusat Cipto Mangunkusumo (RSCM) menyatakan jumlah pasien yang sedang menjalani hemodialisis dalam 2 tahun terakhir diperkirakan sekitar 60-100 pasien. Pesatnya perkembangan di bidang teknologi dan medis kedokteran memungkinkan pasien GGT menjalani hemodialisis, sehingga memiliki harapan hidup yang lebih lama. Di sisi lain komplikasi yang mungkin timbul akibat penyakit dan proses hemodialisis membutuhkan kerja sama antar berbagai bidang ilmu, termasuk dokter gigi, untuk menangani pasien secara komprehensif., ${ }^{4,5}$

Cukup banyak laporan tentang adanya masalah oral yang dikeluhkan pasien GGT yang sedang menjalani hemodialisis. ${ }^{6-8}$ Keluhan ini kemungkinan terkait dengan proses penyakit ginjal, penggunaan obat serta proses hemodialisis. ${ }^{6-9}$ Adanya kelainan di mulut tersebut dapat menganggu asupan nutrisi pasien, padahal nutrisi yang adekuat diperlukan oleh pasien hemodialisis. Hal ini memungkinkan terjadi defisiensi nutrisi, yang pada akhirnya dapat memperburuk kualitas hidup pasien. Pengenalan dini dan penatalaksanaan pasien GGT yang menjalani hemodialisis, beserta dengan manifestasi di regio orofasial, termasuk di dalamnya penilaian fungsi kelenjar saliva dapat mencegah komplikasi atau efek merugikan lebih lanjut dan membantu meningkatkan kualitas hidup pasien. ${ }^{6}$

Dari penelusuran literatur, penelitian mengenai serostomia dan disfungsi kelenjar saliva pada pasien GGT yang menjalani hemodialisis masih terbatas. Sementara penelitian mengenai masalah mulut pada pasien GGT dengan hemodialisis juga masih sedikit. ${ }^{10}$ Selain itu, walaupun penurunan laju alir saliva telah dilaporkan terjadi pada pasien GGT yang menjalani hemodialisis, namun faktor penyebab keadaan tersebut belum diketahui pasti dan masih diperlukan penelitian lebih lanjut. ${ }^{6}$

Di Indonesia sendiri data tersebut belum jelas, padahal masalah di mulut akan memperburuk kualitas hidup pasien. Berdasarkan data buku catatan pasien, sepanjang tahun 2003 terdapat 24 pasein GGK yang dirujuk ke poli gigi dan mulut bagian ilmu penyakit mulut untuk evaluasi dan tata laksana masalah gigi dan mulut. Dari pemeriksaan didapatkan sejumlah kelainan yang dapat menjadi masalah bagi pasien GGT. Namun karena keterbatasan waktu dan alat, pemeriksaan yang dilakukna terbatas pada pemeriksaan rutin, sehingga data yang tersedia tidak memadai. Selain itu data masalah kelainan orofasial yang dijumpai pada pasien GGT yang menjalani hemodialisis di RSCM juga belum tersedia. Atas dasar pertimbangan tersebut, maka diperlukan penelitian tentang kelainan orofasial termasuk perubahan saliva yang terjadi pada pasien GGT yang menjalani hemodialisis.

\section{METODE}

Penelitian observasional potong lintang ini dilakukan pada pertengahan Januari sampai akhir Febuari 2005, di bagian hemodialisis Rumah Sakit Umum Pusat Nasional Cipto Mangunkusumo (RSUPN-CM).

\section{Subjek}

Sembilan puluh tiga dari 124 (75\%) pasien berusia antara 17 sampai 78 tahun yang memenuhi kriteria inklusi menjadi subjek dalam penelitian ini. Kriteria subjek yang ditetapkan adalah semua pasien GGT yang menjalani hemodialisis di RSUPN-CM pada saat penelitian sedang dilakukan, kondisi umum pasien memungkinkan untuk dilakukan pemeriksaan klinis, pengukuran saliva dan bersedia mengikuti penelitian sampai selesai dengan menandatangani lembar persetujuan. 
Pasien GGT dengan dialisis praoperatif atau dialisis temporer, kondisi kesadaran pasien menurun sehingga tidak memungkinkan untuk dilakukan pemeriksaan klinis dan pengukuran saliva, atau yang tidak komunikatif dan tidak dapat bekerja sama menurut peneliti tidak disertakan dalam penelitian.

\section{Bahan dan alat}

Alat yang digunakan untuk pemeriksaan klinik adalah instrumen standar kedokteran gigi dan senter diagnostik. Pemeriksaan saliva dilakukan dengan kertas lakmus $\mathrm{pH}$ berindikator (GC Asia Dental), dan saliva buffer test kit (GC Asia Dental). Lembar rekam medik pasien digunakan untuk mendapatkan data demografi, riwayat medis, dan status hemodialisis. Kuesioner yang terkait dengan serostomia, disgesia, rasa metal, perdarahan gingiva, rasa nyeri pada mukosa mulut dan lidah, dan perioral anesthesia juga disertakan.

\section{Prosedur}

Data demografi, data riwayat medis dan status hemodialisis diperoleh dari rekam medik dan wawancara langsung oleh peneliti kepada subjek penelitian atau anggota keluarganya jika data yang diperoleh sebelumnya kurang jelas. Wawancara terstruktur meliputi pertanyaan-pertanyaan mengenai keluhan subjektif terkait kelainan regio orofasial (serostomia, disgesia, rasa metal, rasa nyeri pada lidah dan atau mukosa mulut, perioral anesthesia).

Data objektif diperoleh dengan melakukan pemeriksaan klinis pada mukosa jaringan lunak regio orofasial (kelenjar parotis, kelenjar limfe submandibula, bibir, mukosa labial atas dan bawah, mukosa bukal kiri dan kanan, gingiva, palatum durum, palatum molle, lidah (dorsum, ventral, lateral kiri dan kanan), dan dasar mulut) yang dilakukan saat subjek sedang menjalani prosedur hemodialisis.

Kelainan jaringan lunak regio orofasial yang diperiksa adalah dysgeusia, rasa metal, nyeri mukosa atau lidah, perioral anesthesia, serostomia, pembesaran asimptomatik kelenjar saliva (sialosis), bau uremik, stomatitis uremik, kandidiasis oral, mukosa mulut pucat, bercak hemoragik (ptekie dan ekimosis), perdarahan gingiva, tongue coating, deposisi kalkulus, inflamasi /pembesaran gingiva. Penilaian sialosis dilakukan secara visual dan palpasi akan adanya pembesaran kelenjar saliva parotis yang asimptomatik, bilateral, tanpa inflamasi dan bukan merupakan keganasan. Data serostomia diperoleh dengan mencatat riwayat keluhan pasien dan riwayat medis, menggunakan kuesioner Fox dan ditunjang dengan pemeriksaan klinis adanya mukosa mulut yang tampak kering serta pengukuran laju aliran saliva untuk melihat ada tidaknya hiposalivasi. Pemeriksaan bau uremik dilakukan secara organoleptik.

Karakteristik saliva yang diperiksa dalam penelitian ini meliputi laju aliran saliva keseluruhan tanpa dan dengan stimulasi, $\mathrm{pH}$, kapasitas dapar, tingkat hidrasi mukosa labial bawah dan tingkat viskositas saliva

Pengukuran saliva dengan metode spitting, pada saliva keseluruhan tanpa dan dengan stimulasi paraffin wax (GC Asia Dental) dilakukan sebelum prosedur hemodialisis dimulai. Pengukuran $\mathrm{pH}$ dan kapasitas dapar saliva dilakukan dengan kertas lakmus khusus berindikator dan saliva buffer test kit (GC Asia Dental) sesuai petunjuk pabrik. Tingkat hidrasi mukosa labial diperiksa secara visual dengan mengamati kecepatan pembentukan butiran saliva dari orifis kelenjar saliva minor di mukosa labial bawah untuk menilai tingkat hidrasi mukosa mulut. Penilaian viskositas saliva dilakukan secara visual terhadap saliva keseluruhan tanpa stimulasi. Pada penelitian ini juga dilakukan pemeriksaan kebersihan mulut dan status dental, sebab hal ini berpengaruh pada kondisi mulut secara keseluruhan. Pemeriksaan meliputi pengukuran skor Oral Hygiene Index Simplified (OHI-S), serta pengukuran skor Decay, Missing, Filling Teeth (DMF-T).

\section{HASIL}

Sembilan puluh tiga pasien memenuhi kriteria inklusi, terdiri dari 57 (61,3\%) pasien laki-laki dan $36(38,7 \%)$ pasien perempuan (Tabel 1). Sebagian besar subjek (79,6\%) yang diperiksa telah menjalani hemodialisis selama 0,5 sampai 10 tahun. Rata-rata durasi hemodialisis adalah 6,02 (SD 4,91) tahun, dengan rentang 0,5 sampai 21 tahun. Etiologi GGT yang terbanyak dijumpai adalah glomerulonefritis yaitu $42(45,2 \%)$ kasus. Sebanyak 18 $(19,3 \%)$ subjek tidak diketahui etiologinya, termasuk $3(3,2 \%)$ dengan rekam medik yang tidak lengkap. Sedangkan riwayat penggunaan rutin jamu atau obatobatan yang diketahui memiliki efek nefrotoksik ditemukan pada $23(24,7 \%)$ subjek penelitian.

Medikasi yang mungkin berkaitan dengan kelainan di mulut dan sedang dikonsumsi oleh subjek penelitian pada saat pemeriksaan, adalah anti hipertensi pada 68 $(73,1 \%)$ subjek, serta anti koagulan atau anti platelet pada $9(10 \%)$ subjek. Anti hipertensi yang dikonsumsi meliputi golongan ACE inhibitor, anti adrenergic, -blocker, Ca channel blocker dan diuretik. Sementara itu riwayat medikasi 10 subjek tidak dapat diketahui.

Seluruh subjek menunjukkan 1 atau lebih tanda dan atau gejala kelainan jaringan lunak regio orofasial. Karakteristik dan distribusi frekuensi kelainan tersebut dapat dilihat pada Tabel 2. Lesi mulut yang merupakan manifestasi oral khas GGT yaitu stomatitis uremik ternyata tidak ditemukan pada penelitian ini.

Pada seluruh subjek dijumpai lapisan (coating) yang menutupi dorsum lidah dengan berbagai kategori ketebalan. Deposit kalkulus dan inflamasi gingiva dijumpai pada 91 (97,8\%) subjek. Temuan klinis lain 
yang perlu dicermati karena dijumpai pada sebagian besar subjek adalah adanya cheilitis pada $92(98,9 \%)$ subjek, fissured tongue pada seluruh subjek, atropi lateral lidah pada $66(71,0 \%)$ subjek dan atrisi gigi pada $79(84,9 \%)$ subjek.

Pengukuran laju aliran saliva keseluruhan tanpa stimulasi menunjukkan nilai rata-rata sebesar 0,29(SD $0,33) \mathrm{ml} /$ menit. Sebanyak $21(22,6 \%)$ subjek termasuk kategori hiposalivasi (laju aliran saliva di bawah $0,1 \mathrm{ml} /$ menit). Sedangkan untuk pengukuran laju aliran saliva keseluruhan dengan stimulasi sebanyak 29(31,2\%) subjek termasuk kategori hiposalivasi (laju aliran saliva lebih kecil dari 0,7ml/menit) (Tabel 3 dan 4).

Rata-rata $\mathrm{pH}$ saliva subjek adalah 7,24(SD 0,55). Sebanyak 75(80,6\%) subjek mempunyai $\mathrm{pH}$ saliva yang cenderung basa. Rata-rata kapasitas dapar adalah 10,44(SD 2,28). Sebanyak 71(76,3\%) subjek memiliki kapasitas dapar saliva yang tinggi, $17(18,3 \%)$ subjek termasuk kategori sedang, sedangkan 5(5,4\%) subjek dijumpai termasuk kategori rendah.

Mayoritas yaitu 74(79,6\%) subjek memiliki tingkat hidrasi rendah dan peningkatan viskositas saliva. Sebagian besar subjek yaitu 80(86\%) subjek memiliki saliva yang bergelembung dan berbuih dan bahkan pada $13(14 \%)$ subjek viskositas salivanya lengket dan berbuih (Tabel 4). Rata-rata laju aliran saliva tanpa dan dengan stimulasi pada subjek penelitian yang mengalami sialosis ternyata lebih rendah bila dibandingkan dengan yang tidak mengalami sialosis. Demikian juga dengan nilai rata-rata $\mathrm{pH}$, kapasitas dapar, tingkat hidrasi, dan viskositasnya.

Tabulasi silang antara keluhan serostomia dan sialosis, menunjukkan dari 70 subjek dengan sialosis, sebanyak $60(85,7 \%)$ subjek mengeluhkan adanya serostomia. Sedangkan sebanyak 17(73,9\%) subjek merasa serostomia, namun tidak dijumpai sialosis dan pada 6 $(26,1 \%)$ subjek tidak dijumpai kedua kelainan tersebut (Tabel 5)

Selanjutnya dilakukan eksplorasi data (Tabel 6) dan dijumpai rata-rata laju aliran saliva keseluruhan tanpa dan dengan stimulasi pada subjek penelitian yang mengalami serostomia dan sialosis ternyata lebih rendah bila dibandingkan dengan yang tidak mengalami hal tersebut.

Eksplorasi pada faktor-faktor yang mungkin terkait dengan laju aliran saliva tanpa dan dengan stimulasi, yaitu dengan penggunaan obat anti hipertensi, serostomia, dan dysgeusia juga menunjukkan bahwa rata-rata laju aliran saliva lebih rendah pada kelompok subjek yang menggnakan obat, serta mengalami serostomia dan dysgeusia (Tabel 7). Sebanyak 83 $(89,2 \%)$ subjek memiliki kebersihan mulut buruk dan
Tabel 1. Distribusi frekuensi pasien gagal ginjal terminal yang sedang menjalani hemodialisis di RSUPN-CM pada bulan Januari-Febuari 2005 menurut kelompok umur dan jenis kelamin $(\mathrm{n}=93)$

\begin{tabular}{|c|c|c|c|c|}
\hline \multirow{2}{*}{$\begin{array}{l}\text { Kelompok usia } \\
\text { (Tahun) }\end{array}$} & \multicolumn{2}{|c|}{ Jenis kelamin } & \multirow[t]{2}{*}{ Jumlah } & \multirow[t]{2}{*}{ (\%) } \\
\hline & Laki-laki (\%) & Perempuan (\%) & & \\
\hline $10-19$ & $3(3,2)$ & $0(0,0)$ & 3 & 3,2 \\
\hline $20-29$ & $3(3,2)$ & $0(0,0)$ & 3 & 3,2 \\
\hline $30-39$ & $6(6,5)$ & $3(3,2)$ & 9 & 9,7 \\
\hline $40-49$ & $19(20,4)$ & $17(18,3)$ & 36 & 38,7 \\
\hline $50-59$ & $13(14)$ & $11(11,8)$ & 24 & 25,8 \\
\hline $60-69$ & $10(10,8)$ & $4(4,3)$ & 14 & 15,1 \\
\hline $70-79$ & $3(3,2)$ & $1(1,1)$ & 4 & 4,3 \\
\hline Jumlah & $57(61,3)$ & $36(38,7)$ & 93 & 100,0 \\
\hline $\begin{array}{l}\text { Rata-rata usia } \\
\text { (tahun) }\end{array}$ & $49,97 \pm 12,33$ & & & \\
\hline
\end{tabular}

Tabel 2. Distribusi frekuensi karakteristik kelainan jaringan lunak regio orofasial pada pasien gagal ginjal terminal yang sedang menjalani hemodialisis di RSUPN-CM pada bulan Januari-Febuari 2005 ( $n=93)$

\begin{tabular}{|c|c|c|c|c|c|c|}
\hline $\begin{array}{l}\text { Karakteristik } \\
\text { kelainan jaringan } \\
\text { lunak regio } \\
\text { orofasial }\end{array}$ & Ya & $\%$ & Tidak & $\%$ & Jumlah & $\%$ \\
\hline $\begin{array}{l}\text { Gangguan } \\
\text { pengecapan } \\
(\text { dysgeusia })\end{array}$ & 62 & 66,7 & 31 & 33,3 & 93 & 100,0 \\
\hline $\begin{array}{l}\text { Rasa metal (metal } \\
\text { taste) }\end{array}$ & 53 & 57,0 & 40 & 43,0 & 93 & 100,0 \\
\hline $\begin{array}{l}\text { Nyeri mukosa atau } \\
\text { lidah }\end{array}$ & 31 & 33,3 & 62 & 66,7 & 93 & 100,0 \\
\hline Perioral anesthesia & 23 & 24,7 & 70 & 75,3 & 93 & 100,0 \\
\hline Serostomia & 77 & 82,8 & 16 & 17,2 & 93 & 100,0 \\
\hline Sialosis & 70 & 75,3 & 23 & 24,7 & 93 & 100,0 \\
\hline $\begin{array}{l}\text { Bau uremik } \\
\text { (Uremic Odor) }\end{array}$ & 38 & 40,9 & 55 & 59,1 & 93 & 100,0 \\
\hline $\begin{array}{l}\text { Stomatitis uremik } \\
\text { (Uremic Stomatitis) }\end{array}$ & 0 & 0,0 & 93 & 100,0 & 93 & 100,0 \\
\hline Angular cheilitis & 35 & 37,7 & 58 & 62,3 & 93 & 100,0 \\
\hline $\begin{array}{l}\text { Pseudomembranous } \\
\text { Candidiasis }\end{array}$ & 3 & 3,2 & 90 & 96,8 & 93 & 100,0 \\
\hline Mukosa pucat & 88 & 94,6 & 5 & 5,4 & 93 & 100,0 \\
\hline Bercak hemoragik & 37 & 39,8 & 56 & 60,2 & 93 & 100,0 \\
\hline $\begin{array}{l}\text { Perdarahan } \\
\text { gingival }\end{array}$ & 14 & 15,1 & 79 & 84,9 & 93 & 100,0 \\
\hline Tongue coating & 93 & 100,0 & 0 & 0,0 & 93 & 100,0 \\
\hline Deposit kalkulus & 91 & 97,8 & 2 & 2,2 & 93 & 100,0 \\
\hline Inflamasi gingival & 91 & 97,8 & 2 & 2,2 & 93 & 100,0 \\
\hline \multicolumn{7}{|l|}{ Lain-lain: } \\
\hline Cheilitis & 92 & 98,9 & 1 & 1,1 & 93 & 100,0 \\
\hline Fissured Tongue & 93 & 100,0 & 0 & 0,0 & 93 & 100,0 \\
\hline $\begin{array}{l}\text { Atropi lateral } \\
\text { lidah }\end{array}$ & 66 & 71,0 & 27 & 29,0 & 93 & 100,0 \\
\hline Atrisi gigi & 79 & 84,9 & 14 & 15,1 & 93 & 100,0 \\
\hline
\end{tabular}


Tabel 3. Distribusi frekuensi perbandingan antara keluhan serostomia dan hasil pengukuran laju aliran saliva keseluruhan pada pasien gagal ginjal terminal yang sedang menjalani hemodialisis di RSUPN-CM pada bulan JanuariFebuari $2005(\mathrm{n}=93)$

\begin{tabular}{|c|c|c|c|c|}
\hline \multirow{2}{*}{$\begin{array}{l}\text { Kriteria laju aliran } \\
\text { saliva keseluruhan }\end{array}$} & \multicolumn{2}{|c|}{ Serostomia } & \multirow[t]{2}{*}{ Jumlah } & \multirow[t]{2}{*}{$\%$} \\
\hline & Ya & Tidak & & \\
\hline \multicolumn{5}{|l|}{ Tanpa stimulasi } \\
\hline $\begin{array}{l}\text { Hiposalivasi }(<0,1 \mathrm{ml} / \\
\text { menit) }\end{array}$ & 21 & 0 & 21 & 22,6 \\
\hline $\begin{array}{l}\text { Di bawah kisaran } \\
\text { normal }\end{array}$ & 27 & 5 & 32 & 34,4 \\
\hline$(0,1>-<0,3 \mathrm{ml} / \mathrm{menit})$ & & & & \\
\hline $\begin{array}{l}\text { Normal }(0,3-0,4 \mathrm{ml} / \\
\text { menit })\end{array}$ & 18 & 5 & 23 & 24,7 \\
\hline $\begin{array}{l}\text { Di atas kisaran normal } \\
(>0,4 \mathrm{ml} / \text { menit })\end{array}$ & 11 & 6 & 17 & 18,3 \\
\hline Jumlah & 77 & 16 & 93 & 100,0 \\
\hline Dengan stimulasi & & & & \\
\hline $\begin{array}{l}\text { Hiposalivasi }(<0,7 \mathrm{ml} / \\
\text { menit) }\end{array}$ & 26 & 3 & 29 & 31,2 \\
\hline $\begin{array}{l}\text { Di bawah kisaran } \\
\text { normal }\end{array}$ & 19 & 0 & 19 & 20,4 \\
\hline $\begin{array}{l}(0,7>-<1 \mathrm{ml} / \mathrm{menit}) \\
\text { Normal }(1-3 \mathrm{ml} / \mathrm{menit})\end{array}$ & 28 & 10 & 38 & 40,9 \\
\hline $\begin{array}{l}\text { Di atas kisaran normal } \\
>(3 \mathrm{ml} / \text { menit })\end{array}$ & 4 & 3 & 7 & 7,5 \\
\hline Jumlah & 77 & 16 & 93 & 100,0 \\
\hline
\end{tabular}

sisanya memiliki kebersihan mulut sedang. Rata-rata skor OHI-S adalah 5,34 (SD 0,88). Sebanyak 7 (7,5\%) subjek tidak dapat disertakan dalam penghitungan skor OHI-S, karena jumlah gigi yang tersisa tidak mewakili regio yang diperlukan dalam penghitungan atau subjek menggunakan gigi tiruan.

Pada pengukuran skor DMF-T ditemukan hanya 10 (10,8\%) dari 93 subjek yang bebas karies dan tumpatan serta memiliki jumlah gigi lengkap. Sebanyak 4 (4,3\%) subjek tidak dapat dihitung skor DMF-T, karena jumlah gigi yang tersisa tidak mewakili untuk penghitungan. Skor DMF-T populasi yang diperoleh adalah 5,61, yang menurut kriteria WHO termasuk kategori rendah, yaitu dalam rentang 1,6-6,2. Laju karies subjek dihitung dengan rata-rata skor Decay populasi yaitu 2,64.

\section{PEMBAHASAN}

Pada penelitian ini, GGT lebih banyak ditemukan pada kelompok usia 40-69 tahun, dengan rata-rata usia subjek adalah 49,97 tahun dan tidak terdapat kecenderungan gender (Tabel 1).
Tabel 4. Distribusi frekuensi karakteristik saliva pasien gagal ginjal terminal yang sedang menjalani hemodialisis di RSUPN-CM pada bulan Januari-Febuari $2005(n=93)$

\begin{tabular}{|c|c|c|}
\hline Karakteristik saliva & Jumlah & $\%$ \\
\hline \multicolumn{3}{|l|}{ pH Saliva } \\
\hline Asam $\quad(<5.8)$ & 2 & 2,2 \\
\hline Moderat (6.0-6.6) & 16 & 17,2 \\
\hline Basa $\quad(6.8-7.8)$ & 75 & 80,6 \\
\hline Jumlah & 93 & 100,0 \\
\hline Rata-rata $\mathrm{Ph}$ & $7,24 \pm 0,55$ & \\
\hline \multicolumn{3}{|l|}{ Kapasitas Dapar Saliva } \\
\hline Rendah (0-5) & 5 & 5,4 \\
\hline Sedang (6-9) & 17 & 18,3 \\
\hline Tinggi $(10-12)$ & 71 & 76,3 \\
\hline Jumlah & 93 & 100,0 \\
\hline Rata-rata kapasitas dapar & $10,44 \pm 2,28$ & \\
\hline
\end{tabular}

Tingkat Hidrasi Mukosa Labial

bawah

\begin{tabular}{lcc}
\hline Rendah (>60 detik) & 74 & 79,6 \\
Normal (30-60 detik) & 17 & 18,3 \\
Tinggi $\quad(<30$ detik $)$ & 2 & 2,2 \\
Jumlah & 93 & 100,0
\end{tabular}

Viskositas Saliva

\begin{tabular}{lcc}
\hline Jernih dan encer seperti air & 0 & 0,0 \\
Bergelembung dan berbuih & 80 & 86,0 \\
Lengket dan berbuih & 13 & 14,0 \\
Jumlah & 93 & 100,0 \\
\hline
\end{tabular}

Penelitian dilakukan di RSUPN-CM dengan karakteristik sebagian besar subjek penelitian termasuk golongan sosial ekonomi menengah ke bawah dan biaya perawatannya ditanggung ASKES. Hal ini mempengaruhi tingkat pemahaman, kesadaran dan sikap subjek terhadap pemeliharaan kesehatan gigi dan mulut, termasuk kepatuhan pasien akan instruksi medis terkait dengan kondisinya, yang pada akhirnya berperan pada kelainan-kelainan orofasial yang mungkin dijumpai.

Pada pasien GGT yang menjalani hemodialisis dilaporkan dapat dijumpai sejumlah manifestasi orofasial., ${ }^{6,7}$ Pada penelitian ini pada seluruh subjek dijumpai 1 atau lebih tanda dan atau gejala kelainan jaringan lunak orofasial (Tabel 2). Jenis temuan klinis tersebut sesuai dengan manifestasi oral subjek GGT dengan hemodialisis yang dinyatakan pada berbagai literatur.

Pada penelitian ini, dysgeusia ditemukan pada 62 $(66,7 \%)$ subjek dan dari anamnesis beberapa subjek mengeluhkan adanya gangguan rasa manis dan asam, serta mulut terasa pahit. Hal ini sesuai dengan beberapa penelitian terdahulu yang melaporkan adanya 
Tabel 5. Distribusi frekuensi dan proporsi antara sialosis dan serostomia pada pasien gagal ginjal terminal yang sedang menjalani hemodialisis di RSUPN-CM pada bulan Januari-Febuari 2005 ( $\mathrm{n}=93)$

\begin{tabular}{lccc}
\hline \multirow{2}{*}{$\begin{array}{l}\text { Pembesaran kelenjar } \\
\text { Parotis (Sialosis) }\end{array}$} & \multicolumn{2}{c}{ Serostomia } & \\
\cline { 2 - 3 } Ya & $60(85,7)$ & Tidak (\%) & Jumlah \\
Tidak & $17(73,9)$ & $6(26,1)$ & 70 \\
Jumlah & 77 & 16 & 23 \\
\hline
\end{tabular}

Tabel 6. Distribusi frekuensi perbandingan sialosis dan serostomia dengan karakteristik saliva pasien gagal ginjal terminal yang sedang menjalani hemodialisis di RSUPN-CM pada bulan Januari-Febuari 2005 ( $\mathrm{n}=93$ )

\begin{tabular}{ccccccc}
\hline $\begin{array}{c}\text { Kriteria } \\
\text { Sialosis }\end{array}$ & $\begin{array}{c}\text { LASKTS* } \\
\text { (ml/menit) }\end{array}$ & $\begin{array}{c}\text { LASKDS** } \\
\text { (ml/menit) }\end{array}$ & pH & Dapar & Hidrasi & Viskositas \\
\hline Ya & 0,22 & 0,99 & 7,18 & 10,29 & 1,16 & 1,84 \\
Tidak & 0,48 & 1,41 & 7,41 & 10,91 & 1,43 & 1,91 \\
\hline Kriteria & $\begin{array}{c}\text { LASKTS* } \\
\text { (ml/menit) }\end{array}$ & $\begin{array}{c}\text { LASKDS** } \\
\text { (ml/menit) }\end{array}$ & $\mathbf{p H}$ & Dapar & Hidrasi & Viskositas \\
\hline Ya & 0,24 & 1,03 & 7,20 & 10,44 & 1,18 & 1,84 \\
Tidak & 0,50 & 1,43 & 7,41 & 10,44 & 1,44 & 1,94 \\
\hline
\end{tabular}

* Laju Aliran Saliva Keseluruhan Tanpa Stimulasi

* * Laju Aliran Saliva Keseluruhan Dengan Stimulasi

Tabel 7. Distribusi frekuensi perbandingan laju aliran saliva tanpa dan dengan stimulasi, penggunaan anti hipertensi, serostomia dan dysgeusia pada pasien gagal ginjal terminal yang sedang menjalani hemodialisis di RSUPN-CM pada bulan Januari-Febuari $2005(\mathrm{n}=93)$

\begin{tabular}{ccccccc}
\hline Laju Aliran Saliva & \multicolumn{2}{c}{ Obat hipertensi } & \multicolumn{2}{c}{ Serostomia } & \multicolumn{2}{c}{ Disgesia } \\
\cline { 2 - 6 } & Ya & Tidak & Ya & Tidak & Ya & Tidak \\
\hline LASKTS* (ml/menit) & 0,24 & 0,52 & 0,24 & 0,50 & 0,26 & 0,33 \\
LASKDS** (ml/menit) & 1,04 & 1,45 & 1,03 & 1,43 & 1,03 & 1,24 \\
\hline
\end{tabular}

* Laju Aliran Saliva Keseluruhan Tanpa Stimulasi

* *aju Aliran Saliva Keseluruhan Dengan Stimulasi

indikasi bahwa pengecapan terhadap rasa manis dan asam lebih terpengaruh dibandingkan rasa asin dan pahit. 7 Tingginya kadar ureum, dimetil dan trimetil amin dalam saliva dan rendahnya kadar seng diduga terkait dengan penurunan persepsi rasa pada pasien hemodialisis. ${ }^{7}$ Kemungkinan faktor penyebab lainnya adalah adanya gangguan metabolisme dan defisiensi vitamin, yang sering terjadi pada pasien GGT sehingga menyebabkan terjadinya atropi kuncup pengecap. Gangguan pengecapan pada penderita gagal ginjal kronik mungkin juga berkaitan dengan rasa metal, bau uremik, penurunan laju aliran saliva, akumulasi lapisan debris di lidah dan diperburuk oleh kebersihan mulut yang buruk. Pemikiran ini didasari oleh temuan bahwa sejumlah subjek dengan $d y$ sgeusia ternyata juga mengalami keluhan rasa metal dan mulut yang kering, serta bau uremik dan tongue coating. Rasa metal yang dialami pasien hemodialisis diduga terkait dengan adanya kecenderungan perdarahan pada gingiva dan mukosa mulut. Literatur lain mengkaitkan rasa metal dengan tingginya kadar ureum dalam saliva. ${ }^{11}$

Bau uremik yang lazim dijumpai pada penderita gagal ginjal kronik, disebabkan tingginya kadar ureum dalam darah, dimana ureum akan dipecah menjadi ammonia yang kadarnya meningkat dalam saliva sehingga menimbulkan halitosis. ${ }^{12}$ Pada penelitian ini pengukuran bau uremik dilakukan secara organoleptik saja, yaitu dengan indera penghidu oleh peneliti. Diperkirakan bau uremik yang terdeteksi berkaitan dengan tingginya kadar ureum darah. Namun hal ini perlu dibuktikan lebih jauh dengan pemeriksaan laboratorium darah 
kadar ureum dan kreatinin sebagai penunjang, yang pada penelitian ini tidak dilakukan karena keterbatasan penelitian.

Pada penelitian ini nyeri pada mukosa mulut dan atau lidah ditemukan pernah terjadi pada sekitar sepertiga dari keseluruhan subjek. Hal ini sesuai dengan pernyataan bahwa akumulasi kadar ammonia dalam saliva dapat mengiritasi mukosa mulut. ${ }^{7}$ Selain itu beberapa subjek juga pernah merasakan rasa kebas atau seperti kesemutan pada daerah di sekitar mulut dan wajah (perioral anesthesia). Diduga hal ini berkaitan dengan gangguan saraf (neuropati perifer) yang terjadi pada pasien gagal ginjal kronik. Beberapa literatur menyatakan gangguan saraf dapat terjadi pada daerah muka dan perioral, walaupun jarang. ${ }^{2,11}$

Serostomia merupakan keluhan utama pada penelitian ini, yang dijumpai pada 77 (82,8\%) subjek. Namun karena serostomia merupakan keluhan subjektif, yang tidak selalu mencerminkan fungsi dan kondisi kelenjar saliva sesungguhnya, maka serostomia saja tidak dapat menjadi patokan adanya gangguan kelenjar saliva. ${ }^{13,14}$ Temuan serostomia ini sesuai dengan beberapa penelitian terdahulu bahwa serostomia banyak dijumpai dan menjadi keluhan utama pasien GGT. ${ }^{5-8}$ Kemungkinan adanya gangguan atau perubahan pada kelenjar saliva akibat kadar ureum darah yang tinggi akan mempengaruhi penurunan laju aliran saliva dan serostomia. ${ }^{7}$ Selain itu faktor terbatasnya asupan cairan serta pengaruh medikasi seperti anti hipertensi yang memiliki efek samping serogenik berperan pada terjadinya serostomia. ${ }^{6,7,13}$ Sebanyak $68(73,1 \%)$ subjek diketahui mendapat anti hipertensi, meliputi golongan ACE inhibitor, anti adrenergic, $\beta$-blocker, $C a$ channel blocker dan diuretik. Medikasi tersebut diketahui memiliki efek samping serogenik. ${ }^{13}$ Namun karena subjek umumnya menggunakan kombinasi anti hipertensi, tidak dapat diketahui medikasi mana yang lebih dominan pengaruhnya pada kekeringan mulut dan laju aliran saliva.

Sialosis pada penelitian ini dijumpai sebesar $75,3 \%$. Meskipun demikian mekanisme dan etiologi peningkatan insidens sialosis ini belum diketahui. Dari penelusuran literatur mengenai pasien GGT hanya dijumpai sedikit data mengenai perubahan kelenjar saliva. Sialosis dapat ditemukan pada kondisi ketidakseimbangan hormonal, defisiensi nutrisi, alkoholisme, atau gangguan mekanisme kontrol neural. ${ }^{15}$ Pada pasien GGT diperkirakan hal ini terkait dengan kompensasi kelenjar saliva terhadap dehidrasi episodik, ${ }^{6,716}$ defisiensi nutrisi, ${ }^{35}$ serta akibat toksin uremik yang diduga menyebabkan perubahan pada kelenjar saliva. ${ }^{15,16}$ Gangguan fungsi saliva pada pasien hemodialisis terkait dengan atrofi glandular dan fibrosis kelenjar saliva minor. Ia juga menyatakan bahwa uremia dapat mempercepat terjadinya kemunduran fungsi kelenjar terkait dengan proses menua. ${ }^{10,17}$ Selain itu adanya penggunaan medikasi anti hipertensi anti adrenergik (clonidin) diketahui menyebabkan pembesaran kelenjar saliva melalui intervensi fungsi saraf otonom. ${ }^{15}$ Untuk kejelasan patogenesis sialosis dan kaitannya dengan perubahan saliva masih diperlukan penelitian lebih lanjut.

Dari perbandingan antara serostomia dan sialosis, didapatkan persentase serostomia sedikit lebih tinggi dari sialosis. Perbedaan hal ini mungkin disebabkan serostomia merupakan keluhan subjektif yang lebih dipengaruhi toleransi pasien terhadap kondisi penyakitnya. Namun karena penelitian ini adalah penelitian deskriptif maka hasil yang didapatkan tidak dapat dipakai untuk melihat hubungan sebab akibat. Masih diperlukan penelitian lebih lanjut untuk mengetahui apakah sialosis merupakan kompensasi dari keadaan serostomia, atau sebaliknya, serostomia terjadi akibat sialosis mengingat pada penelitian ini juga didapati penurunan rata-rata laju aliran saliva pada penderita sialosis dibandingkan yang tidak mengalami hal tersebut.

Lesi mulut yang merupakan manifestasi oral khas GGT yaitu stomatitis uremik ternyata tidak ditemukan pada penelitian ini. Tidak ditemukannya lesi ini diperkirakan sejalan dengan hemodialisis yang rutin dijalani subjek. Walaupun hilangnya resistensi jaringan dan ketidakmampuan jaringan bertahan terhadap pengaruh traumatik, kebersihan mulut yang buruk diperkirakan juga berperan dalam terjadinya stomatitis uremik. Melalui proses hemodialisis akan terjadi reduksi kadar ureum darah, sehingga mengurangi kemungkinan terjadi stomatitis uremik. Literatur menyebutkan jarangnya stomatitis uremik dan ulserasi intra oral merefleksikan kondisi subjek telah dalam perawatan medis yang memadai. ${ }^{7}$

Dugaan infeksi candida yang ditemukan pada penelitian ini didukung oleh gejala klinis adanya plak-plak putih yang dapat diangkat dan meninggalkan dasar hiperemis. Perlu dilakukan penelitian lanjutan yang disertai konfirmasi pemeriksaan kultur kandida di saliva untuk ketepatan diagnosis. Saliva memegang peranan penting dalam menjaga keseimbangan homeostasis rongga mulut, melalui aktivitas antimikrobial dan fungsi lubrikasi bagi mukosa mulut, sehingga kondisi mulut yang kering dan kebersihan mulut yang buruk akan meningkatkan resiko terjadinya infeksi di rongga mulut.

Mukosa mulut yang pucat $(94,6 \%)$ pada pasien GGT merupakan manifestasi klinis adanya anemia, yang lazim dijumpai pada pasien GGT, yang melibatkan patogenesis multifaktorial. Temuan klinis ini sebaiknya ditunjang dengan pemeriksaan laboratorium darah.

Pada penelitian ini, dijumpai bercak hemoragik pada 37 $(39,8 \%)$ subjek dan perdarahan gingiva pada $14(15,1 \%)$ subjek. Selain itu dari rekam medik pasien diketahui sebanyak 9(9,7\%) subjek mendapat medikasi oral anti koagulan atau anti platelet, yang diduga berkaitan dengan timbulnya bercak hemoragik di mukosa mulut 
dan bahkan perdarahan gingiva secara spontan. Hal ini sesuai dengan literatur yang menyatakan bahwa bercak hemoragik di mukosa atau perdarahan mukosa dan atau gingiva pada pasien GGT, berkaitan dengan defek platelet akibat toksin uremik, serta pengaruh penggunaan medikasi anti koagulan atau anti platelet. ${ }^{2,7}$ Pada subjek yang tidak menggunakan medikasi oral anti koagulan, ternyata juga didapati adanya bercak hemoragik dan perdarahan gingiva pada mukosa mulutnya. Kemungkinan hal ini berkaitan dengan penggunaan heparin dalam prosedur dialisis. Dalam hal ini perlu adanya konfirmasi lebih lanjut dengan pemeriksaan darah.

Pada penelitian ini sesuai dengan literatur ${ }^{7}$, dijumpai tongue coating dengan kategori ketebalan yang bervariasi pada seluruh subjek. Kondisi mulut yang kering sehingga menyebabkan berkurangnya selfcleansing, penggunaan berbagai medikasi sistemik dan kebersihan mulut yang buruk berperan pada terjadinya tongue coating. ${ }^{18}$ Selain itu faktor ketidaktahuan mayoritas pasien bahwa permukaan dorsum lidah perlu dibersihkan pada saat menyikat gigi diduga juga berperan.

Beberapa penelitian terdahulu melaporkan kecenderungan terbentuknya deposit kalkulus yang tinggi. ${ }^{6,719}$ Diduga bahwa gangguan keseimbangan serum fosfat dan kalsium menyebabkan hal tersebut. ${ }^{19}$ Hal ini sesuai dengan temuan pada penelitian ini, di mana pada hampir seluruh subjek ditemukan deposit kalkulus supra dan sub gingiva yang menyeluruh. Kondisi ini ditambah dengan tingginya akumulasi plak menyebabkan kebersihan mulut yang buruk dan sejalan dengan inflamasi gingiva yang ditemukan, yaitu pada $91(97,8 \%)$ subjek. Pada penelitian ini faktor lain yang diduga berperan adalah ketidaktahuan atau ketidakmampuan pasien membersihkan gigi dan mulut dengan baik, atau rendahnya frekuensi subjek ke dokter gigi terkait status sosial ekonominya.

Temuan klinis lain yang dijumpai adalah keilitis, yang bervariasi berupa bibir yang kering, deskuamasi atau berdarah yang diduga berhubungan dengan defisiensi nutrisi dan kondisi dehidrasi cairan tubuh secara keseluruhan, serta terbatasnya asupan cairan yang dapat dikonsumsi pasien. Perlu penelitian lebih lanjut, sebab penulis belum menemukan literatur yang membahas keilitis pada pasien GGT. Pada pemeriksaan juga terlihat kecenderungan terjadinya atrisi permukaan gigi, yang dijumpai pada $79(84,9 \%)$ subjek. Temuan ini sesuai dengan penelitian yang melaporkan frekuensi atrisi yang tinggi pada pasien GGT. Literatur mengkaitkan hal ini dengan proses menua atau kondisi mulut yang kering. Kebiasaan pasien mengunyah es batu untuk mengatasi rasa kering di mulut, karena asupan cairan yang dibatasi mungkin berpengaruh pada kelainan ini. ${ }^{9}$ Selain itu ditemukan adanya fisur-fisur pada dorsum lidah, yang diduga terkait dengan kondisi mulut yang kering, serta adanya defisiensi nutrisi terutama vitamin B kompleks, akibat gangguan metabolisme pada pasien gagal ginjal kronik. Fisur pada dorsum lidah juga lazim dijumpai seiring dengan peningkatan usia dan pada beberapa literatur dikaitkan dengan trauma, defisiensi vitamin dan kelainan perkembangan. ${ }^{20}$ Pada penelitian ini fisur dijumpai terbanyak pada kelompok usia 40-69 tahun. Tidak dapat ditarik kesimpulan apakah peningkatan usia berhubungan dengan fisur, karena sebaran data penelitian ini memang terkumpul pada kelompok usia tersebut. Melihat fisur yang dijumpai pada seluruh subjek, mungkin dapat dilakukan penelitian lebih lanjut untuk melihat adakah kaitan GGT, hemodialisis dan fisur pada lidah.

Pada penelitian ini perubahan saliva dilihat dari penurunan laju aliran saliva keseluruhan, baik tanpa dan dengan stimulasi, $\mathrm{pH}$ dan kapasitas dapar saliva, serta pengukuran tingkat hidrasi mukosa labial bawah dan viskositas saliva. Pengukuran laju aliran saliva dengan stimulasi menggunakan stimulasi mekanik, yaitu paraffin wax inert (GC) untuk meminimalkan terjadinya bias pada pengukuran kapasitas dapar. Pada pelaksanaannya dalam penelitian ini, dijumpai beberapa subjek yang ternyata mual saat harus mengunyah paraffin. Hal ini mungkin berpengaruh pada hasil pengukuran laju aliran saliva dengan stimulasi dan dapat menjadi faktor pengganggu pada hasil penelitian ini. Hal lain yang juga berpengaruh adalah waktu pengambilan saliva yang tidak bisa disamakan, karena subjek penelitian terbagi menjadi 2 giliran pagi dan siang dalam menjalani hemodialisis. Dengan demikian kemungkinan efek ritme biologis mempengaruhi hasil pengukuran laju aliran saliva tersebut tidak dapat dihindari. Dijumpai ada perbedaan antara rata-rata laju aliran saliva keseluruhan dengan stimulasi pada kelompok pagi (LASKTS 0,29; LASKDS 1,26) dan siang (LASKTS 0,28; LASKDS 0,95). Hasil tersebut tidak sesuai dengan teori, namun faktor apa yang berpengaruh di sini tidak diketahui. Diperkirakan adanya kerusakan pada kelenjar saliva individual lebih berperan dibandingkan efek ritme biologis yang terjadi. Hal ini masih membutuhkan penelitian lebih lanjut disertai pengukuran fungsi kelenjar saliva. Selain itu diduga pada subjek kelompok siang, faktor dehidrasi dan cuaca yang panas mempengaruhi laju aliran salivanya.

Pada pengukuran laju aliran saliva tanpa stimulasi, subjek yang termasuk kategori hiposalivasi adalah 21 $(22,6 \%)$ subjek, namun sebanyak $32(34,4 \%)$ subjek berada pada ambang batas bawah, yaitu di antara $0,1-0,3 \mathrm{ml} / \mathrm{menit}$. Hal ini sesuai dengan literatur yang menunjukkan adanya kecenderungan penurunan laju aliran saliva pada pasien GGT yang menjalani hemodialisis. ${ }^{4,6,7,10}$ Penurunan laju aliran saliva ini disebabkan kombinasi keterlibatan langsung uremik pada kelenjar saliva serta dehidrasi yang terkait pembatasan asupan cairan. ${ }^{4,6,7}$ Namun subjek penelitian ini diketahui seringkali tidak mematuhi anjuran dokter dalam membatasi asupan cairan dan hal ini mungkin berpengaruh pada hasil pengukuran laju aliran saliva. 
Sedangkan pada pengukuran laju aliran saliva dengan stimulasi, temuan hiposalivasi dijumpai pada 29 $(31,2 \%)$ subjek. Normalnya laju aliran saliva dengan stimulasi adalah sekitar $1-2 \mathrm{ml} / \mathrm{menit}^{13}$ dan hiposalivasi bila nilainya lebih kecil dari $0,7 \mathrm{ml} / \mathrm{menit}^{21}$ Data subjek dengan keadaan hiposalivasi mendukung hasil penelitian terdahulu bahwa memang terjadi gangguan fungsi kelenjar saliva yang menyebabkan reduksi sekresi saliva pada pasien GGT dengan hemodialisis. ${ }^{10,17}$

Sebagian subjek penelitian memiliki keluhan mulut kering, meskipun yang benar-benar termasuk hiposalivasi hanya $21(22,6 \%)$ subjek (saat tanpa stimulasi) dan 29(31,2\%) subjek (dengan stimulasi). Sejumlah subjek masih memiliki laju aliran saliva normal, namun mengeluhkan adanya mulut kering. Hal sebaliknya dapat terjadi bahwa ada subjek dengan penurunan laju aliran saliva, tetapi tidak merasa mulutnya kering, yang mungkin disebabkan adanya toleransi dari mekanisme tubuh pasien. Literatur menyebutkan bahwa serostomia memang dapat terjadi tanpa disertai penurunan laju aliran saliva dan sebaliknya bisa dialami oleh subjek dengan aliran saliva normal. ${ }^{13} \mathrm{Hal}$ ini perlu dikonfirmasi lebih lanjut dengan tes fungsi kelenjar saliva. Pada penelitian ini didapati juga laju aliran saliva subjek yang di atas kisaran normal. Diduga hal ini disebabkan subjek tersebut mengalami hipersalivasi atau karena ada perbedaan waktu pengukuran laju aliran saliva. Pada penelitian sebelumnya diketahui bahwa neuropati diabetes berperan pada penurunan laju aliran saliva dan serostomia. ${ }^{22}$ Namun peranan mekanisme neuopati pada pasien GGT terhadap penurunan laju aliran saliva dan serostomia belum diketahui jelas, jadi perlu penelitian lebih lanjut.

Sesuai dengan hasil penelitian terdahulu, $\mathrm{pH}$ saliva keseluruhan tanpa stimulasi pada subjek penelitian ini dijumpai cenderung tinggi atau basa. ${ }^{23,24} \mathrm{Hal}$ ini disebabkan tingginya konsentrasi amonia dalam saliva akibat hidrolisis urea oleh mikroorganisme oral. ${ }^{12}$ Meskipun pada penelitian ini kadar fosfat saliva tidak diperiksa secara spesifik, namun dilakukan pengukuran kapasitas dapar dengan menggunakan kit khusus (GC corp). Akan lebih baik bila dilakukan penelitian lanjutan disertai pemeriksaan kadar fosfat saliva. Hasil yang diperoleh menunjukkan sebagian besar subjek termasuk memiliki kapasitas dapar yang tinggi. Perubahan keseimbangan serum fosfat dan kalsium berakibat pada tingginya konsentrasi fosfat dalam saliva dan berpengaruh pada peningkatan kapasitas dapar saliva. Hal ini dapat menjadi suatu keuntungan bagi subjek, terutama yang mengalami hiposalivasi, karena $\mathrm{pH}$ dan kapasitas dapar saliva yang tinggi akan memperkecil kemungkinan terjadinya karies.

Pada penelitian ini juga didapatkan data yang di luar perkiraan, yaitu ada subjek yang memiliki $\mathrm{pH}$ tinggi, namun ternyata kapasitas daparnya rendah. Diduga ada faktor eksternal lain yang menyebabkan hal ini.
Untuk konfirmasi temuan ini sebaiknya dilakukan analisa komponen saliva yang lain. Subjek penelitian juga diperiksa tingkat hidrasi mukosa mulutnya dan hampir $80 \%$ subjek termasuk kategori rendah. Hal ini menggambarkan adanya gangguan pada fungsi kelenjar saliva minor pada mukosa mulut dan menunjang data penurunan laju aliran saliva. Sebanyak $2(2,2 \%)$ subjek ternyata memiliki tingkat hidrasi tinggi, yang diduga berkaitan dengan usia subjek tersebut yang relatif muda dan durasi penyakit relatif masih sebentar, yaitu sekitar 1 tahun.

Viskositas saliva subjek yang mayoritas adalah kental dan berbuih sesuai dengan gambaran klinis adanya hiposalivasi, yaitu laju aliran saliva menurun dan viskositas saliva meningkat. Hal ini disebabkan adanya kondisi dehidrasi secara umum yang berpengaruh pada penurunan jumlah cairan pembentuk saliva. ${ }^{13,25}$

Menurut literatur kebersihan mulut pasien hemodialisis cenderung buruk, mungkin berkaitan dengan kondisi penyakit dan proses hemodialisis itu sendiri telah menyita waktu dan perhatian subjek, sehingga kebersihan mulut cenderung terabaikan. ${ }^{12,26}$ Padahal kebersihan gigi dan mulut sangat penting, apalagi dalam kaitannya dengan rentannya pasien gagal ginjal kronik terhadap infeksi. ${ }^{14,26}$ Kebersihan gigi dan mulut yang buruk akan menjadi fokus infeksi yang dapat menyebar lokal, menimbulkan septikemia, menyebar jauh dan bahkan menyebabkan kemunduran kondisi sistemik pasien, yang pada akhirnya akan memperburuk kualitas hidup pasien.

\section{SIMPULAN}

Kelainan-kelainan yang ditemukan sebagian besar sesuai dengan yang tertera di berbagai literatur, namun ada beberapa hal yang spesifik pada penelitian ini. Keluhan utama yang ditemukan adalah adanya serostomia, sedangkan kelainan orofasial yang paling banyak adalah tongue coating.

Pengenalan dini dan penanganan gangguan pada kelenjar saliva pada pasien hemodialisis perlu mendapat perhatian khusus. Hal ini disebabkan adanya penurunan laju aliran saliva dan mulut yang kering dapat menjadi predisposisi kelainan mulut lainnya. Mukosa mulut yang kering akan mudah terluka dan menyebabkan asupan nutrisi pasien terganggu, yang pada akhirnya akan menurunkan kualitas hidup pasien., ${ }^{4,6}$ Dengan demikian temuan kelainan orofasial pada pasien GGT dengan hemodialisis ini membutuhkan penatalaksanaan komprehensif yang lebih lanjut.

Penelitian ini dapat menjadi dasar dan perlu ditindaklanjuti dengan penelitian-penelitian lain pada pasien GGT yang menjalani hemodialisis. 


\section{DAFTAR PUSTAKA}

1. Abboud H, Henrich WL. Clinical practice. Stage IV chronic kidney disease. N Engl J Med. 2010;362:56-65.

2. Watnick SW, Morrison G. Kidney. In Current Medical Diagnosis \& Treatment 2003. 42nd ed. New York : Lange Medical Books/McGraw-Hill. 2003: 877-85.

3. National Institute of Diabetes and Digestive and Kidney Diseases. Kidney Diseases of Diabetes. Available from: http://kidney.niddk.nih.gov/ kudiseases/pubs/kidneyfailure/index.htm. 2003

4. Bayraktar G, Kazancioglu R, Bozfakioglu S, Ecder T, Yildiz A, Ark E. Stimulated salivary flow rate in chronic hemodialysis patients. Nephron. 2002;91:210-4.

5. De Rossi SS, Glick M. Dental considerations for the patient with renal disease receiving hemodialysis. J Am Dent Assoc. 1996;127:211-9.

6. Kao CH, Hsieh JF, Tsai SC, Ho YJ, Chang HR. Decreased salivary function in patients with endstage renal disease requiring hemodialysis. Am J Kidney Dis. 2000;36:1110-4.

7. Kho HS, Lee SW, Chung SC, Kim YK. Oral manifestations and salivary flow rate, $\mathrm{pH}$, and buffer capacity in patients with end-stage renal disease undergoing hemodialysis. Oral Surg Oral Med Oral Pathol Oral Radiol Endod. 1999;88:3169.

8. Martins C, Siqueira WL, Oliveira E, Nicolau J, Primo LG. Dental calculus formation in children and adolescents undergoing hemodialysis. Pediatr Nephrol. 2012;27:1961-6.

9. Klassen JT, Krasko BM. The dental health status of dialysis patients. J Can Dent Assoc. 2002;68:34-8.

10. Postorino M, Catalano C, Martorano C, Cutrupi S, Marino C, Cozzupoli P, Scudo P, Zoccali C. Salivary and lacrimal secretion is reduced in patients with ESRD. Am J Kidney Dis. 2003;42:722-8.

11. Nandan RK, Sivapathasundharam B, Sivakumar G. Oral manifestations and analysis of salivary and blood urea levels of patients under going haemo dialysis and kidney transplant. Indian J Dent Res. 2005;16:77-82.

12. Greabu M, Battino M, Mohora M, Totan A, Didilescu A, Spinu T, Totan C, Miricescu D, Radulescu R. Saliva--a diagnostic window to the body, both in health and in disease. J Med Life. 2009;2:124-32.

13. Streckfus C, Bigler L, O'Bryan T. Aging and salivary cytokine concentrations as predictors of whole saliva flow rates among women: a preliminary study. Gerontology. 2002;48:282-8.

14. Al-Maweri SA, Ismail NM, Ismail AR, AlGhashm A. Prevalence of oral mucosal lesions in patient with type 2 diabetes attending hospital universiti sains Malaysia. Malays J Med Sci. 2013;20:39-46.

15. Ferguson DB. The Salivary Glands and their secretions. In Oral Bioscience. Edinburgh: Churchill Livingstone. 1999: 117-50.

16. Gavalda C, Bagan JV, Scully C, Silvestre FJ, Millian Ma, Jimenez Y. Renal hemodialysis patients: oral, salivary, dental and periodontal findings in 105 adult cases. Oral Dis. 1999;5:299302.

17. Seraj B, Ahmadi R, Ramezani N, Mashayekhi A, Ahmadi M. Oro-dental health status and salivary characteristics in children with chronic renal failure. J Dent (Tehran). 2011;8:146-51.

18. Dawes C. Factors Influencing Salivary Flow Rate and Composition. In Saliva and Oral Health. $2^{\text {nd }}$ ed. London: British Dental Association. 1996: 27-42.

19. Waheed AA, Pedraza F, Lenz O, Isakova T. Phosphate control in end-stage renal disease: barriers and opportunities. Nephrol Dial Transplant. 2013;28:2961-8.

20. de la Rosa García E, Mondragón Padilla A, Aranda Romo S, Bustamante Ramírez MA. Oral mucosa symptoms, signs and lesions, in end stage renal disease and non-end stage renal disease diabetic patients. Med Oral Patol Oral Cir Bucal. 2006;11:E467-73.

21. Walsh LJ. GC Team. Saliva Testing. Good Practice, Good Sense. Singapore: GC Asia Dental Pte Ltd Changi Inetrnational Logistics Centre. 2002.

22. Moore PA, Guggenheimer J, Etzel KR, Weyant RJ, Orchard T. Type 1 diabetes mellitus, xerostomia, and salivary flow rates. Oral Surg Oral Med Oral Pathol Oral Radiol Endod. 2001;92:281-91.

23. Leão JC, Gueiros LA, Segundo AV, Carvalho AA, Barrett W, Porter SR. Uremic stomatitis in chronic renal failure. Clinics (Sao Paulo). 2005;60:259-62.

24. Summers SA, Tilakaratne WM, Fortune F, Ashman N. Renal disease and the mouth. Am J Med. 2007;120:568-73.

25. Chavez EM, Taylor GW, Borrell LN, Ship JA. Salivary function and glycemic control in older persons with diabetes. Oral Surg Oral Med Oral Pathol Oral Radiol Endod. 2000;89:305-11.

26. Jain S, Singla A, Basavaraj P, Singh S, Singh K, Kundu $\mathrm{H}$. Underlying kidney disease and duration of hemodialysis: an assessment of its effect on oral health. J Clin Diagn Res. 2014;8:ZC65-9. 